\title{
The Impact of Human Resource Management Practices on Perceived Organizational Support and Organizational Commitment: A Study of Deluxe Hotels in Hurghada, Egypt
}

\author{
Yasser Ibrahim Abu Elnasr Sobaih Gaber Gabry
}

\begin{abstract}
This research studies the impact of the human resource management (HRM) practices of hotel employees on their perceived organizational support (POS) and organizational commitment (OC). The study also analyzes the impact of socio-demographic factors on OC. Data for this study was collected via selfadministrated questionnaires with employees from 36 hotels in Hurghada. The study revealed that correlations between HRM practices and both of employees' POS and AC were positive and significant. There was also significant positive relationship between POS and AC. The regression analysis results demonstrated that HRM practices had a strong significant relationship to employees' OC and POS. Moreover, POS was found to partially mediate the relationship between HRM practices and AC. The findings revealed that proper use of HRM practices would make the employees more committed to their hotels. The results suggest that the hotels HR managers should put great emphasis on employees to stimulate job commitment and to develop clear practical framework for which to analyze, assess and potentially guide the influence of HRM practices on POS and the influence of POS on OC.
\end{abstract}

Keywords: Human Resource Management (HRM), Perceived Organizational Support (POS), Organizational Commitment (OC), Affective Commitment (AC), Organizational Support Theory (OST).

\section{Introduction}

Providing quality service is one of the major concerns for hotel operators. Employees play a primary role in delivering quality service; however, jobs in the industry have been characterized by insufficient salaries and training (Poulston, 2008), low job morale and high turnover (Deery \& Shaw, 1999), few benefits, low job security, and long working hours (Dawson et al., 2011, Sobaih, 2015). Additionally, the hotel industry is widely noted to have a poor reputation for its ability to handle !as those policies aimed to foster commitment among employees, creating highly involved employees who identify with the organization. Employees' perceptions of an organization's commitment to them are referred to as perceived organizational support 


\section{The Impact of Human Resource Management Practices on Perceived Organizational Support and Organizational Commitment: A Study of Deluxe Hotels in Hurghada, Egypt}

(POS) (Eisenberger et al., 1986). POS is the degree to which employees believe that their!.

It is argued that adopting specific HRM practices can improve organizational performance and sustain competitiveness (Chang, 2005; Guest, 2011). Despite the important role of HRM, there is no clear practical framework in the literature to analyze, assess and potentially guide the influence of HRM practices on POS, followed by the influence of POS on OC. This research addresses this gap by analyzing the HRM practices role in enhancing OC of hotel employees and provides a basis for further inquiry. Addressing this research gap is important because HRM practices may provide a behavioral model, which helps senior managers to focus on practicing HRM, to manage intense market competition. Therefore, the main aim of this study is to examine the impact of human resource management (HRM) practices on perceived organizational support (POS) and organizational commitment (OC). The study examines four relationships. First, it examines the influence of HRM practices on POS. Second, it examines the influence of HRM practices on OC. Third, it tests the influence of POS on OC. Fourth, it examines the mediating effect of POS on the relationship between HRM practices and OC. Moreover, the study analyzes the impact of sociodemographic factors on OC.

\section{Theoretical Framework}

\section{HRM Practices and Perceived Organizational Support}

A review of literature revealed that many studies were commonly use ability, motivation and opportunity (AMO) theory to study and evaluate the HRM practices (Appelbaum et al., 2000; Boxall \& Purcell, 2008). According to the AMO theory, organizational performance is a function of employee ability, motivation and opportunity to participate. Employees will perform well in a job when: (1) they possess the knowledge and skills required to perform that job (abilities); (2) they are adequately interested and incentivized to do that job (motivation); and (3) their work environment supplies the required support and avenues for expression (opportunity to participate) (Boxall \& Purcell, 2008). In other words, HRM systems will be most effective when they foster ability, motivation and opportunity to contribute to effectiveness (Boselie et al., 2005; Purcell \& Hutchinson, 2007). For example, job autonomy and involvement in decision making are regarded as being fundamental in promoting opportunities to participate and contribute discretionary effort (Appelbaum et al., 2000). Thus, management use of appropriate HRM practices can help positively influence employee attitudes 
and behaviors, and these attitudes and behaviors, in turn, will have a positive influence on organizational performance (Boselie, 2010).

The social exchange theory (SET) (Blau, 1964) and organizational support theory (OST) (Eisenberger et al., 1986) suggested that employees who receive high levels of support from the organization are tending to repay the organization. Employees, who have higher POS might become more engaged to their job and organization in order to help the organization reach its objectives (Rhoades et al., 2001). Ogilvie (1986) proposed that employees' perceptions of HRM practices reflect a sense of reciprocity, when employees believe that their organization is concerned about them and cares about their well-being, they are likely to respond by attempting to fulfill their obligations to the organization by becoming more engaged.

According to OST, if employees perceive more support from the organization, they are likely to show greater attendance and efforts, which in turn, lead to better performance (Eisenberger et al., 1986; Rhoades \& Eisenberger, 2002). One essential way to reciprocate the organization's favorable treatment is through continued participation (Allen et al., 2003). HRM practices and policies have been suggested as influencing factors to increase POS among employees (Meyer \& Smith, 2000). Bartlett (2001) indicated that employees perceived the availability of training as support from their employer, which made them more committed to their organization. POS has been shown to be influenced by HRM practices such as training and development, career development opportunities, work-family support, employee engagement and organization's recognition of individual achievement through practices such as promotions, salary increases (e.g., Wayne et al., 2002; Liu, 2004; Ram \& Prabhakar, 2011). Based on the pervious discussion this study hypothesizes that:

Hypothesis 1: Human resource management (HRM) practices positively affect perceived organizational support (POS).

\section{HRM Practices and Organizational Commitment}

Organizational commitment has three components: affective, continuance and normative commitment. Affective commitment (AC) refers to an employee's emotional attachment to an organization and continuance commitment refers to an employee's awareness of the costs associated with leaving the organization whereas normative commitment reflects a perceived obligation to stay with the organization (Meyer et al., 1993). Meyer and Allen (1997, p. 67) indicated that 'AC is the most desirable form of commitment and the one that organizations are most likely want to instill in their employees'. Accordingly, AC is preferred by researchers as the central concept of OC and

is used as the only indicator of OC in many recent studies. It has been found to significantly correlate with a wider range of desirable outcomes than both continuance and normative commitment (Kehoe \& Wright, 2013). Therefore, 


\section{The Impact of Human Resource Management Practices on Perceived Organizational Support and Organizational Commitment: A Study of Deluxe Hotels in Hurghada, Egypt}

the current study focuses on the affective component of OC. The effective implementation of high performance HRM practices such as training, job security, promotion and communication, will lead to supportive work environments which are likely to cause employees to feel an obligation to the goals of the organization and develop an affective attachment to it (Kehoe \& Wright, 2013). Maxwell and Steele (2003) identified some key issues that would increase the commitment level such as: high levels of equal pay, employer's interest in them, co-operation and trust between the employees, and opportunities to engage in social activities. Research on HRM and OC has shown positive relationship between high performance HRM practices and OC (e.g. Kwon et al., 2010; Messersmith et al., 2011; Yang, 2012; Takeuchi \& Takeuchi, 2013). Moreover, several studies examined the effect of HRM practices on the attitudes of employees and showed that HRM practices had a significant positive effect on OC (e.g. Kehoe \& Wright, 2013). For example, Yang (2012) found that high involvement HRM practices had significant positive effects on employees' AC which in turn had significant positive effects on their display of organizational citizenship behavior (OCB).

A number of studies have also examined the relationship between the individual HRM practices that comprise high performance work systems and OC. For instance, Appelbaum et al. (2000) indicated that autonomy in decision making, formal training, employment security, pay for performance, fair pay, company help in dealing with work and family issues, and promotion opportunities had significant positive relationships with OC. Likewise, Bartlett (2001) found that access to training, support for training from senior staff and colleagues, perceived benefits of training, and motivation had significant positive relationships with OC. Gould-Williams and Gatenby (2010) affirmed that performance related reward schemes, training and development, and performance appraisals had significant positive effects on the commitment of workers. Moreover, Katou and Budhwar (2010) indicated that job evaluation, compensation, promotion, incentives, and benefits had significant positive effects on employee commitment. Cantarello et al. (2012) found that multi-task training, integration, and team working had significant positive relationships with OC. Gardner et al. (2011) explained that formal performance evaluations, merit pay, bonuses, promotion opportunities, complaint processes, crossdepartment and company communication, and formal participation programs had a significant positive relationship with AC. Chang (2005) argued that employee organizational commitment was increased because HRM practices send messages to employees about the organization's commitment to them, which in turn makes the employees more committed to their organizations. 
Based on the empirical findings discussed in this section, the research proposes that:

Hypothesis 2: Human resource management (HRM) practices positively affect employees' affective commitment (AC).

\section{Perceived Organizational Support and Organizational Commitment}

Important organizational outcome that might result from perceived organizational support is commitment to the organization. POS has been found to be related to a number of favorable outcomes like job satisfaction and OC (Rhoades \& Eisenberger, 2002). OST suggested that POS, which is an indicator of the organization's commitment to the employee, creates an obligation within the employee to care about the organization and reciprocate with commitment and loyalty (Eisenberger et al., 1986). Based on the reciprocity norm, organizational actions indicating caring of and concern for employees may enhance OC. Empirical support has been found for a positive relationship between POS and OC (Eisenberger et al., 2001). Meta-analysis suggested that the overall effect size for the relationship between POS and OC is large (Rhoades \& Eisenberger, 2002). Employees tend to reciprocate the organization's support with higher commitment, in an attempt to help maintain their self-image, avoid the stigma associated with violation of the reciprocity norm, and encourage future favorable treatment from the organization (Eisenberger et al., 2001). Rhoades et al. (2001) used repeated measures of POS and AC to assess the direction of causality between these two variables, and their results suggested that POS contributed to changes in AC over time. Moreover, Research showed that those with high organizational support perceptions develop strong psychological commitment state (Van Knippenberg \& Sleebos, 2006). A complementary argument is made by the organizational support theory (OST) that hypothesizes that employees view the HRM practices as indicative of investments in them by organization, which in turn, determines their attitudes and behaviors (Eisenberger \& Stinglhamber, 2011). Additionally, Meyer and Smith (2000) found that the relationship of HRM practices and AC was largely mediated by perceptions of organizational support. Therefore, it is expected that employee perceived organizational support mediates the relationship between HRM practices and AC. Based on the pervious discussion the study $\begin{array}{lllllllllllllllll}\mathrm{h} & \mathrm{y} & \mathrm{p} & \mathrm{o} & \mathrm{t} & \mathrm{h} & \mathrm{e} & \mathrm{s} & \mathrm{i} & \mathrm{z} & \mathrm{e} & \mathrm{s} & \mathrm{t} & \mathrm{h} & \mathrm{a} & \mathrm{t} & \text { : }\end{array}$

Hypothesis 3: Perceived organizational support (POS) positively affects employees' affective commitment (AC).

Hypothesis 4: Perceived organizational support (POS) will mediate the relationship between HRM practices and employees' affective commitment (AC). 
The research hypotheses aforementioned are expressed in the proposed research model shown in Figure 1. The figure depicts a simple mediation model, where HRM practices represent the independent variable, POS is the mediator and $\mathrm{AC}$ is the dependent variable. According to Iacobucci et al. (2007), the proportion of mediation could be determined by comparing the magnitude of the indirect to total (direct plus indirect) path coefficients. In Figure 1, $a$ represents the standardized path coefficient from the independent variable to the mediator, $b$ represents the standardized path coefficient from the mediator to the dependent variable and $\mathrm{c}^{\prime}$ represents the standardized path coefficient from the independent to the dependent variable. If both $a$ and $b$ are significant there is prima facie evidence of mediation. This could be attained using the following equation:

$$
\text { Proportion of Mediation }=\frac{a \times b}{(a \times b)+c^{\prime}}
$$

Figure 1: The research proposed model

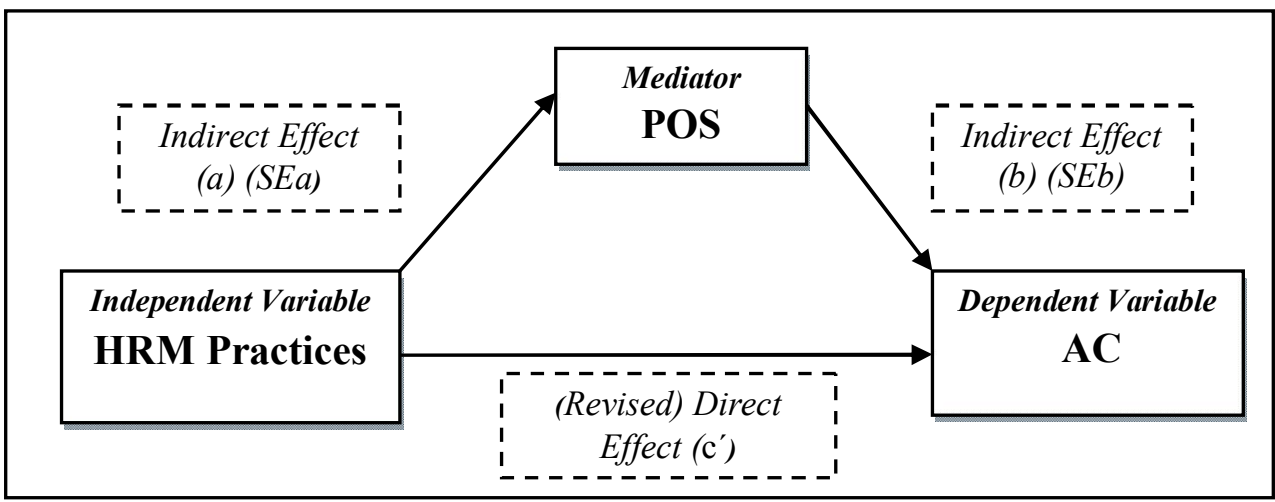

$\mathrm{a}=$ regression coefficient for the association between the IV and mediator; SEa $=$ standard error of $\mathrm{a} ; \mathrm{b}=$ raw coefficient for the association between the mediator and the DV (when the IV is also a predictor of the DV); $\mathrm{SEb}=$ standard error of $b$.

\section{Methodology}

\section{Sample and Data Collection}

The population frame for this study is the list of all five and four-star resort hotels in Hurghada. According to statistics from Egyptian Hotel Association (2016), there are 23 five-star and 46 four-star resorts and hotels in Hurghada. A convenience sample method was used in this study. A sample of 36 resort hotels (14 five-star and 22 four-star) were purposively selected to achieve the aim of the study. These hotels and resorts were mostly managed by 
international or local chains and were selected in this study since they have the privilege of their chain's accumulated experience, standard operating procedures, continuous training, periodical surveying of employees' opinions, and scheduled programs for employees' satisfaction. Data were obtained via self-administrated questionnaires with hotel employees from various departments as; front office, housekeeping, food and beverage, maintenance, and recreation. The data collection process was conducted over three month period during the moderately high summer season in 2015. One thousand, two hundred and fifty questionnaires were self-administered, 841 questionnaires were received, 87 questionnaires were discarded because of missing data or obviously inappropriate responses. Therefore, 754 questionnaires were valid for further analysis, resulting in a response rate of 67.3 percent. The response rate of the present study compares favorably with the rate suggested by Baruch and Holtom (2008), which was 52.7 percent.

\section{Research Instrument}

The questionnaire used in the current study comprised of four parts. The first part addressed demographic variables; information was gathered on employees' characteristics including: gender, age, educational level, tenure with hotel, position, department, and type of hotel. The second part explored the HRM practices of the hotels perceived by employees and the third part asked employees about their POS while the forth section measured their AC. HRM practices were measured using a 22-item scale based on prior literature of the HRM practices (Hoque, 1999; Edgar \& Geare, 2005; Kehoe \& Wright, 2013). The HRM practices were bundled according to AMO framework. POS was measured with seven items from the scale developed by Eisenberger et al. (1986). AC was measured using a six-item scale (Meyer et al., 1993). Items for each scale are presented in Table (1) and Table (2). In all scales, respondents were asked to indicate their agreement on a 7-point Likert scale where $1=$ strongly disagree and $7=$ strongly agree.

The study employed an Arabic version of the questionnaire in addition to the English version. A back-translation method was used (McGorry, 2000), in order to ensure the accuracy of the meanings in the instrument and to ensure the equivalence of meaning among the items and constructs between the Arabic and English versions of the instruments. Based on the translation process and the reliability estimates, the Arabic-translated version of the questionnaires seemed to be a valid and reliable measure for data collection.

Prior to data analysis, it was important to establish the reliability and validity of the scales used in this study. Reliability judges the degree to which measures are free from error and therefore yield consistent results. One of the most commonly used measures of reliability is the Cronbach's alpha coefficient (Peterson, 1994). Although the scales used have previously been 
tested for reliability, it was considered appropriate to repeat the tests given the unfamiliar hotel context. Cronbach's alpha was calculated for the total 22 -item HRM practices scale, with a result of 0.839 . Reliability coefficients for the AC 6-item scale was 0.79 and for the POS 7-item scale was 0.70 . These reliability estimates seemed consistent and acceptable with previous research of Meyer et al. (1993) who reported high reliability estimates for the 6-item affective commitment scale with coefficient alpha of 0.87 ), and the reliability of the POS scale assessed by Eisenberger et al. (1986) was 0.87 . Moreover, all these reliability estimates are higher than the generally accepted minimum reliability level of 0.6 as indicated by Peterson (1994). Finally, the questionnaire was piloted, pre-tested and adjusted to improve content validity. The validity was also assessed by seven experts in the field of hotel management education and business administration. Consequently, it is concluded that the scales used in this study are acceptably reliable and valid.

\section{Results And Discussions}

Statistical Package for the Social Sciences (SPSS) software, version 19.0 was used to analyze the collected data. Frequencies were used to analyze the profile of respondents. Descriptive statistics; i.e. mean and standard deviation were used to analyze the scales. Pearson correlation and regression analyses were used to test the research hypotheses. Proportion of mediation and Sobel $\mathrm{z}$ test (Sobel, 1982) was used as means of testing the mediation.

\section{Profile of the Sample}

As shown in Table 3, 4.9\% of the respondents were females and $95.1 \%$ were males. This coincides with the results of Sobaih (2015) that the vast majority of resort workers in Egypt are males. As for the age of respondents, more than half of the respondents $(60.1 \%)$ were less than 25 years old, $25.6 \%$ were between 25 and 34, and the rest were above 35 years old, the average employee age of the respondents in this study was 26.6 years. 
Table 1: HRM Practices Measurement Descriptive Statistics

\begin{tabular}{|c|c|c|c|c|}
\hline Construct & \multicolumn{2}{|r|}{ Item Description } & \multirow{2}{*}{$\begin{array}{c}\text { Mean } \\
4.39\end{array}$} & \multirow{2}{*}{$\begin{array}{c}\text { SD } \\
1.79\end{array}$} \\
\hline \multirow{6}{*}{ Ability } & HRM1 & Applicants undergo structured interviews before being hired. & & \\
\hline & HRM2 & Applicants for this job take formal tests before being hired. & 3.75 & 1.69 \\
\hline & HRM3 & Sufficient on-the-job training programs are provided for employees. & 3.83 & 1.69 \\
\hline & HRM4 & Sufficient off-the-job training programs are provided for employees. & 4.24 & 1.85 \\
\hline & HRM5 & Equal employment opportunity is promoted within this hotel. & 4.38 & 1.85 \\
\hline & & & 4.12 & 1.34 \\
\hline \multirow{9}{*}{ Motivation } & HRM6 & Employees have clear career paths within the hotel. & 3.94 & 1.71 \\
\hline & HRM7 & $\begin{array}{l}\text { The hotel fills the new positions with people from inside the hotel } \\
\text { rather than recruit from outside. }\end{array}$ & 4.35 & 1.77 \\
\hline & HRM8 & $\begin{array}{l}\text { Employees in this job regularly receive a formal evaluation of their } \\
\text { performance. }\end{array}$ & 4.21 & 1.77 \\
\hline & HRM9 & $\begin{array}{l}\text { The pay is related to the personal performance through some sort of } \\
\text { performance or merit-related pay. }\end{array}$ & 3.87 & 1.69 \\
\hline & HRM10 & Employees get sufficient benefits- other than pay. & 4.06 & 1.68 \\
\hline & HRM11 & Job security is almost guaranteed to employees. & 3.86 & 1.72 \\
\hline & HRM12 & My working conditions here are good. & 4.49 & 1.72 \\
\hline & HRM13 & $\begin{array}{l}\text { Hotel spends enough money on health \& safety and I always feel safe } \\
\text { working here in these conditions. }\end{array}$ & 4.32 & 1.72 \\
\hline & & & 4.14 & 1.20 \\
\hline \multirow{10}{*}{ Opportunity } & HRM14 & $\begin{array}{l}\text { Employees in this job regularly reacie formal communication regarding } \\
\text { hotel goals and objectives. }\end{array}$ & 4.60 & 1.78 \\
\hline & HRM15 & $\begin{array}{l}\text { Employees complete an employee attitude survey on a regular } \\
\text { basis. }\end{array}$ & 3.73 & 1.89 \\
\hline & HRM16 & $\begin{array}{l}\text { Employees are involved in formal participation processes, such as } \\
\text { quality improvement groups. }\end{array}$ & 4.13 & 1.82 \\
\hline & HRM17 & $\begin{array}{l}\text { Employees get sufficient opportunities to express views on issues and } \\
\text { concerns at work. }\end{array}$ & 4.38 & 1.69 \\
\hline & HRM18 & $\begin{array}{l}\text { Employees are given influence in hotel decisions that affect their job } \\
\text { or work. }\end{array}$ & 3.85 & 1.76 \\
\hline & HRM19 & $\begin{array}{l}\text { The hotel helps employees to achieve a balance between home life } \\
\text { and work. }\end{array}$ & 3.99 & 1.77 \\
\hline & HRM20 & $\begin{array}{l}\text { My employer asks my opinions about how I can improve my job and } \\
\text { making the hotel successful. }\end{array}$ & 3.80 & 1.74 \\
\hline & HRM21 & $\begin{array}{l}\text { Deliberate design of jobs to make full use of workers' skills and work } \\
\text { organized around team working. }\end{array}$ & 4.44 & 1.79 \\
\hline & HRM22 & $\begin{array}{l}\text { My department gives me considerable opportunity for independence } \\
\text { and freedom in how I do the work. }\end{array}$ & 4.39 & 1.91 \\
\hline & & & 4.15 & 1.33 \\
\hline
\end{tabular}


The Impact of Human Resource Management Practices on Perceived Organizational Support and Organizational Commitment: A Study of Deluxe Hotels in Hurghada, Egypt

Table 2: AC and POS Measurement Descriptive Statistics

\begin{tabular}{|c|l|l|c|c|}
\hline Construct & Item's label & Mean & SD \\
\hline \multirow{4}{*}{$\begin{array}{c}\text { Perceived } \\
\text { Organizationa } \\
\begin{array}{c}\text { Support } \\
\text { (POS) }\end{array}\end{array}$} & POS1 & My employer cares about my well-being. & 4.38 & 1.85 \\
\cline { 2 - 5 } & POS2 & $\ldots$. values my contributions to its well being. & 4.20 & 1.83 \\
\cline { 2 - 5 } & POS3 & $\ldots$. cares about my opinions. & 4.05 & 1.75 \\
\cline { 2 - 5 } & POS4 & $\ldots$. considers my goals and values. & 3.85 & 1.65 \\
\cline { 2 - 5 } & POS5 & $\ldots$. cares about my general satisfaction at work. & 3.69 & 1.72 \\
\cline { 2 - 5 } & POS6 & $\ldots$. is willing to help me when I need a special favor. & 3.92 & 1.67 \\
\cline { 2 - 5 } & POS7 & $\ldots$. shows big concern for me. & 3.89 & 1.84 \\
\cline { 2 - 5 } & & & 4.00 & \\
\hline \multirow{4}{*}{$\begin{array}{c}\text { Affective } \\
\text { Commitment } \\
(\text { AC) }\end{array}$} & AC1 & $\begin{array}{l}\text { I would be very happy to spend the rest of my } \\
\text { career with this hotel }\end{array}$ & 4.08 & 1.75 \\
\cline { 2 - 5 } & AC2 & I really feel as if this hotel's problems are my own. & 4.16 & 1.82 \\
\cline { 2 - 5 } & AC3 & I feel like part of the family at my hotel. & 4.22 & 1.85 \\
\cline { 2 - 5 } & AC5 & I feel emotionally attached to this hotel. & 4.15 & 1.66 \\
\hline & This hotel has a great deal of personal meaning for \\
me. & 4.13 & 1.79 \\
\cline { 2 - 5 } & AC6 & I feel a strong sense of belonging to my hotel. & 4.29 & 1.91 \\
\cline { 2 - 5 } & & 4.17 & \\
\hline
\end{tabular}

As for educational level of the respondents, more than one-third of the respondents $(36.6 \%)$ had a bachelor's degree, $(38.9 \%)$ had high school degree or equivalent intermediate vocational education, $(23.3 \%)$ had a 2 -year diploma degree and only 9 respondents (1.2\%) did not complete high school. The occupational distribution of the respondents varied widely. The largest group of the respondents was food and beverage service employees (38.3\%) followed by housekeeping employees $(22.7 \%)$, kitchen employees $(11.4 \%)$, front office employees (11\%), recreation employees (10.9\%) and finally, maintenance employees $(5.7 \%)$. Regarding the length of service in their current hotels, more than half of the respondents $(56.8 \%)$ worked in their current hotels for 1 to less than 5 years, 33.8\% worked for less than one year, $8.5 \%$ worked for more than 5 years and less than 10 years and only 7 respondents $(0.9 \%)$ worked in their hotels for more than 10 years. The majority of respondents (81.4\%) work in entry level positions, and only $18.6 \%$ of respondents are from the supervisory level. $43 \%$ of respondents were employed in five-star hotels, and the rest were employed in four-star hotels. 
Table 3: Profile of the Respondents $(n=754)$

\begin{tabular}{|c|c|c|c|}
\hline Characteristics & & Frequency & Percent \\
\hline \multirow{2}{*}{ Gender } & Male & 717 & 95.1 \\
\hline & Female & 37 & 4.9 \\
\hline \multirow{4}{*}{ Age } & Less than 25 years & 453 & 60.1 \\
\hline & 25-34 years & 193 & 25.6 \\
\hline & $35-44$ years & 104 & 13.8 \\
\hline & 45 years and above & 4 & 0.5 \\
\hline \multirow{4}{*}{ Marital Status } & Married with no children & 65 & 8.6 \\
\hline & Married with children & 108 & 14.3 \\
\hline & Divorced with children & 8 & 1.1 \\
\hline & Single & 573 & 76.0 \\
\hline \multirow{4}{*}{$\begin{array}{c}\text { Highest Educational } \\
\text { Qualification }\end{array}$} & Did not complete high school & 9 & 1.2 \\
\hline & High school degree/equivalent & 293 & 38.9 \\
\hline & 2-year diploma degree & 176 & 23.3 \\
\hline & Bachelor's degree & 276 & 36.6 \\
\hline \multirow{4}{*}{ Length of Service } & Less than a year and more than 6 months & 255 & 33.8 \\
\hline & 1 to less than 5 years & 428 & 56.8 \\
\hline & 5 to less than 10 years & 64 & 8.5 \\
\hline & 10 years or more & 7 & 0.9 \\
\hline \multirow{2}{*}{ Position } & Entry Level & 614 & 81.4 \\
\hline & Supervisory Level & 140 & 18.6 \\
\hline \multirow{6}{*}{ Department } & Front Office & 83 & 11 \\
\hline & Housekeeping & 171 & 22.7 \\
\hline & Food and beverage service & 289 & 38.3 \\
\hline & Kitchen & 86 & 11.4 \\
\hline & Recreation & 82 & 10.9 \\
\hline & Maintenance & 83 & 5.7 \\
\hline \multirow{2}{*}{ Type of Hotel } & 5 star & 324 & 43 \\
\hline & 4 star & 430 & 57 \\
\hline
\end{tabular}

\section{Testing the research hypotheses}

As shown in Table 1, employees exhibited a moderate mean score for the items that comprised the three HRM bundles, namely, ability (4.12), motivation (4.14) and opportunity (4.15). This implies that on average, the respondents have positive perceptions of these practices. Nevertheless, there are notable variations in the responses to all the items measuring HRM practices. For instance, the means of the items measuring selection $(\mathrm{HRM} 2=$

3.75) and on job training (HRM3 = 3.83) were less than the average of the 
scale (4.12). In the same direction, the mean of the job security item (HRM11 $=3.86$ ) was less than the scale average (4.14). The findings in Table 2 reveal that the respondents had moderately positive levels of POS (mean=4) and AC (mean=4.17). The findings showed that on average, respondents have positive perception of their hotels organizational support. On the other hand, the means of the $\mathrm{AC}$ items suggest that employees are generally committed to their hotels.

Pearson product-moment correlation coefficient was used to examine the relationships between HRM practices and both of POS and AC. Preliminary analyses were performed to ensure no violation of the assumptions of normality, linearity and homoscedasticity. The results revealed that there was a strong positive correlation between HRM practices and POS $(r=.719, \mathrm{n}=$ $754, p<.01)$. There was also a strong positive correlation between HRM practices and $\mathrm{AC}(r=.707, \mathrm{n}=754, p<.01)$. Positive correlation was also found between POS and $\mathrm{AC}(r=.658, \mathrm{n}=754, p<.01)$. These findings are consistent with results of (Meyer et al., 2002).

Pearson product-moment correlation coefficient was also used to examine the relationships among the HRM practices subscales. Results revealed strong positive correlations among the HRM practices subscales $(r=0.661$ to $r=$ 0.708 ). All were statistically significant with $p<.01$. Additionally, the study investigated how the HRM practices subscales correlated with AC and POS. With $(p<.01)$ all the HRM practices bundles subscales had positive, strong, statistically significant correlations with POS, $\mathrm{r}=0.659$ to $r=0.683$, and positive, strong, statistically significant correlations with AC, $r=0.649$ to $r=$ 0.671 (see Table 4). The perceived effects of factors of HRM practices were significantly and positively related to POS, signifying that as the employees' level of perception of the HRM practices effectiveness increases, the level of employees' POS also increases. The results also suggest that there is a strong positive relationship between HRM practices and AC. This suggests that rewards, working conditions, equal employment opportunity and participation are to some extent related to how employees feel about wanting to stay with the hotel. 
Table 4: Pearson product-moment correlations between Ability, Motivation, opportunity, POS and AC

\begin{tabular}{lccccc}
\hline \multicolumn{1}{c}{ Scale } & 1 & 2 & 3 & 4 & 5 \\
\hline 1. Ability & - & $0.661^{* *}$ & $0.697^{* *}$ & $0.666^{* *}$ & $0.671^{* *}$ \\
2. Motivation & & - & $0.708^{* *}$ & $0.659^{* *}$ & $0.649^{* *}$ \\
3. Opportunity & & & - & $0.683^{* *}$ & $0.669^{* *}$ \\
4. POS & & & & - & $0.658^{* *}$ \\
5. AC & & & & - \\
\hline ** Correlation is statistically significant with $p<0.01$. & & &
\end{tabular}

Regression analyses were used to further examine the effects of the HRM practices on both of POS and AC. The results of the regression analyses shown in Table 5 demonstrate significant positive paths from the three bundles of HRM practices to POS $(\beta=0.266, \beta=0.265, \beta=0.385$, and $\mathrm{p}<$ 0.001 , respectively), and significant positive paths from HRM practices to $\operatorname{AC~}(\beta=0.342, \beta=0.281, \beta=0.304$, and $p<0.001$, respectively).

Table 5: Effects of HRM Practices Bundles on POS and AC

\begin{tabular}{lcc}
\hline Relationship & $\begin{array}{c}\text { Standardized } \\
\text { Coefficient }\end{array}$ & t-value \\
\hline Ability $\rightarrow$ POS & 0.266 & $7.180^{* * *}$ \\
Motivation $\rightarrow$ POS & 0.265 & $6.895^{* * *}$ \\
Opportunity $\rightarrow$ POS & 0.385 & $9.280^{* * *}$ \\
Ability $\rightarrow$ AC & 0.342 & $9.503^{* * *}$ \\
Motivation $\rightarrow$ AC & 0.281 & $7.539 * * *$ \\
Opportunity $\rightarrow$ AC & 0.304 & $7.542^{* * *}$ \\
\hline$* * * p<0.001$ & &
\end{tabular}

Regression analysis was further used to test the research hypotheses. Before applying the regression analysis the data was checked to evaluate the regression analysis assumptions. Tests for linearity, homoscedasticity, normality and multicollinearity were performed and the results indicate that all the regression assumptions were upheld.

The results in Table 6 demonstrated significant positive path from HRM practices to POS $(\beta=0.464, p<0.001)$, and significant positive path from HRM practices to $\mathrm{AC}(\beta=0.460, p<0.001)$. The results revealed that the relationship between POS and AC was positive and statistically 
The Impact of Human Resource Management Practices on Perceived Organizational Support and Organizational Commitment: A Study of Deluxe Hotels in Hurghada, Egypt

significant $(\beta=0.226, p<0.001)$. Hence, these results revealed that research hypotheses 1,2 and 3 were supported.

Table 6: Hypotheses Testing Results

\begin{tabular}{lccc}
\hline Hypothesized Relationship & $\begin{array}{c}\text { Standardized } \\
\text { Coefficient }\end{array}$ & t-value & Result \\
\hline Hypothesis 1: HRMP $\rightarrow$ POS & 0.464 & $9.514^{* * *}$ & Supported \\
Hypothesis 2: HRMP $\rightarrow$ AC & 0.460 & $6.654^{* * *}$ & Supported \\
Hypothesis 3: $\mathrm{POS} \rightarrow \mathrm{AC}$ & 0.226 & $4.224 * * *$ & Supported \\
\hline${ }_{* * *}<0.001$ & & &
\end{tabular}

Table 7 shows that the standardized path coefficient from HRM practices to POS and the standardized path coefficient from POS to AC are significant. The coefficient associated with the indirect path of HRM practices via POS to AC equaled $0.105[0.464 \times 0.226]$, and was significantly different from zero (Sobel test $=3.888, S E=0.029, p<0.001$ ). The result also shows that the ratio of indirect to total effect equaled $0.186[0.105 /$ $(0.105+0.460)]$. This indicates that 18.6 percent of the $\mathrm{AC}$ variance explained by both HRM practices and POS was accounted for by the indirect path via POS, whereas the rest of the AC variance explained by both HRM practices and POS was accounted for by the direct path. Thus, the mediation hypothesis (4) was supported.

Table 7: Results of Testing Proportion of Mediation of POS on HRMP-AC Link

\begin{tabular}{|c|c|c|c|c|c|}
\hline Hypothesized Relationship & $\begin{array}{c}\text { HRMP } \square \\
\text { POS } \\
(\boldsymbol{a})\end{array}$ & $\begin{array}{c}\text { POS } \square \\
\text { AC } \\
(\boldsymbol{b})\end{array}$ & $\begin{array}{c}\text { HRMP } \square \\
\text { AC } \\
\left(\boldsymbol{c}^{\prime}\right)\end{array}$ & $\begin{array}{c}\text { Ratio of } \\
\text { Indirect-to- } \\
\text { Total } \\
\text { Effects }\end{array}$ & Result \\
\hline Hypothesis 4: & $0.464^{* * *}$ & $0.226^{* * *}$ & $0.460^{* * *}$ & 0.186 & Supported \\
\hline HRMP $\square \mathrm{POS} \square \mathrm{AC}$ & 0.40001 \\
\hline
\end{tabular}

This study analyzes the impact of socio-demographic factors on AC (see Table 8). The results revealed that age had a significant positive relationship with AC $(p<0.001)$. Older hotel employees were more committed to their hotels than younger workers. This concurs with findings of previous studies that suggest that age has a significant positive relationship with organizational commitment (Meyer et al., 2002). The results found that female workers are more committed to their hotels than male workers. This coincides with Singh et al., (2004) who found that female workers are more 
committed to their organizations than male workers. The results showed that educational level had a significant positive relationship with AC $(p<0.01)$, employees with higher levels of education were more committed to their hotels. This disagrees with previous studies (e.g. Bakan et al., 2011) who reported a significant negative relationship between educational level and affective commitment. The results of the current study showed that tenure with employer had no significant relationship with AC. This contradicts findings of past research which suggests that tenure has significant positive relationship with organizational commitment (Meyer et al., 2002). Moreover, the results showed that position and marital status relationships with organizational commitment were not significant.

Table 8: Effects of Control Variables on AC

\begin{tabular}{|l|c|c|c|}
\hline Control Variable Effect & $\begin{array}{c}\text { Standardized } \\
\text { Coefficient }\end{array}$ & t-value & Relationship \\
\hline Age /Commitment & 0.149 & $4.138^{* * *}$ & Positive \\
\hline Gender/Commitment & 0.073 & $2.007^{* *}$ & Positive \\
\hline Education/Commitment & 0.093 & $2.560^{* *}$ & Positive \\
\hline Tenure/Commitment & -0.018 & -0.486 & None \\
\hline Position/Commitment & 0.043 & 1.181 & None \\
\hline Marital Status/Commitment & -0.048 & -1.328 & None \\
\hline
\end{tabular}

\section{Conclusion And Recommend Ations}

This research investigated the impact of the human resource management (HRM) practices of hotel employees on their perceived organizational support (POS) and organizational commitment (OC). The results signify that as employees' perceptions of the level of HRM practices effectiveness increased, the level of POS also increased. The findings indicate that a greater and effective use of HRM practices will lead to higher POS supporting Hypothesis 1. Previous studies reported a positive relationship between employees' overall perceptions of an organization's HRM practices and POS (e.g. Chang, 2005). The research results provided support to the existing research investigating HRM practices as an antecedent to POS, where HRM explains $46.4 \%$ of the variance in employees perception of the organizational support of the hotel. Liu (2004) found that employees' satisfaction with their pay level would be positively related to POS, and while the relationship between pay level satisfaction and POS was in the

hypothesized direction, this path was only marginally significant $(\beta=.08, p<$ .10 ), employees perceptions of career development opportunities and POS, 


\section{The Impact of Human Resource Management Practices on Perceived Organizational Support and Organizational Commitment: A Study of Deluxe Hotels in Hurghada, Egypt}

was strongly supported $(\beta=.49, p<.001)$, work-family support was also found to have significant positive relationship with $\operatorname{POS}(\beta=.39, p<.001)$, suggesting that employees who believe the organization offers support to help deal with work-family balance issues were more likely to have higher levels of POS.

A significant link was found between HRM practices and AC. The findings suggest that greater use of HRM practices effectiveness would make the employees more committed to the organization supporting Hypothesis 2. This finding is consistent with studies by Chang (2005) and Edgar \& Geare (2005) which found a significant effect of HRM practices on OC. Prior research has highlighted the importance of studying the differential effects of HRM bundles with respect to other variables. For instance, the theoretical study by Wright and Kehoe (2008) proposed that the motivation and opportunity bundles would be positively related to $\mathrm{OC}$, while the ability bundle may have no or a negative impact on commitment. The results showed statistical relationship between ability-enhancing HRM practices and $\mathrm{AC}(\mathrm{r}=0.671, p$ $<0.01$ ). These findings suppose that enhancing skills of employees stipulated by HRM practices, determine the increased organizational commitment. Meaningful statistical relationship is between empowerment-enhancing HRM practices and $\mathrm{AC}(\mathrm{r}=0.669, p<0.01)$. One more meaningful statistical relationship is between motivation-enhancing HRM practices and $\mathrm{AC}(\mathrm{r}=$ $0.649, p<0.01)$. Therefore, it is possible to state that the enhancement of motivation and empowerment allow avoiding or reducing number of employees whose commitment to the organization is low. The results provided support to the existing research investigating HRM practices as an antecedent to $\mathrm{AC}$, where HRM explains $46 \%$ of the variation in their affective commitment to their hotels.

The results demonstrate positive and significant paths from the Ability bundle including training factor to POS $(\beta=0.266)$ and $\mathrm{AC}(\beta=0.342)$. A significant positive relationship between training and OC was reported by Bartlett (2001), and the findings suggested that greater use of training will make employees more committed to the organization. Chang (2005) and (Kusluvan, 2003) included performance appraisal as one of the HRM practices in the HRM commitment package, and the findings suggested that effective use of performance appraisal system would make the employees more committed to their hotels. The results demonstrate positive and significant paths from the Motivation bundle including performance appraisal factor to $\operatorname{POS}(\beta=0.265)$ and $\mathrm{AC}(\beta=0.281)$. 
When employees believe that the organization has fulfilled its obligations, they become more committed to the organization (Coyle-Shapiro \& Kessler, 2000). A direct effect of POS on AC was found in this study supporting Hypothesis 3. The finding is consistent with the results of previous studies that found a significant positive relationship between POS and OC. (i.e. Eisenberger et al., 1986, Shore \& Wayne, 1993, Liu, 2004, Chang, 2005, Zafar et al., 2014). Thus, it can be said by increasing support of organization, $\mathrm{AC}$ and belonging of employees to their hotels are increased. Furthermore, the Hypothesis 4 was supported by the current data. The findings confirm that POS had a partial mediating effect on the relationship between HRM practices and OC and this was consistent with (Meyer \& Smith, 2000). There was partial mediation, but the direct path predominated. This suggests the existence of other mediators of the relationship between high performance HRM practices and AC that still require discovery.

As for socio-demographic factors, the results revealed that older hotel employees and employees with higher levels of education were the most committed to their hotels, and female employees are more committed to their hotels than male employees. Moreover, tenure, position and, marital status had no significant relationship with organizational commitment.

It was anticipated that HRM practices would have a significant influence on POS, which would have a significant influence on AC and which in turn would conclude that HRM practices have a significant influence on AC. According to the study findings, when employees believe that the hotel supports them by providing them good HRM practices, they reciprocate by being more committed to their hotels. This finding is important for the industry and practitioners and they need to focus more on significant HRM practices. Based on the findings, the HR departments should consider the application of proper HRM practices to maintain POS and OC. Hotels should improve working conditions to increase job satisfaction. The findings indicate that improvement of working conditions, promotion, morale conditions, financial rewards, compensation and fringe benefits and participation practices are important factors that affect the satisfaction and in turn will affect the POS and OC. Training and development affects organizational commitment. A well-designed staff development program can assist in raising their morale and organizational commitment, as well as contributing to continuous improvements. Hotels should continue to offer additional training and related workshops/seminars on the components of its HRM program and its impact on performance indicators, organizational commitment and citizenship and job satisfaction. HR departments in hotels 
should enhance social activities, cooperation and trust among employees in order to increase POS and OC.

\section{Limitations and Scope for Future Research}

Perceptions of the employees may not be accurate, resulting in a limitation. The self-report format of the questionnaire poses the problem of honesty in reporting attitudes. Some characteristics of the hotels may have affected the findings, such as their source of funding. Whether they had foreign or local funding may have affected their organizational culture, which in turn could influence the study results. Demographic factors might have affected the results. Moreover, most of the sample chosen came from males, which would strongly open a debate of whether such results would be obtained if gender composition was different. There may have been a self-selection bias among the subordinates who participated in this study since participation was voluntary. There is a question about the generalizability of the study findings to other hospitality organizations such as three-star hotels. Future field studies could address these limitations.

This study provides scope for future studies, with different HRM practices and a different population. A future study could take a larger sample and extend the sampling process beyond Hurghada to include other regions. Future researches could have further study on the other two dimensions of OC; normative commitment, and continuance commitment. However, the study only used a single dimension (i.e. AC). Further investigation of additional individual demographic factors and other organizational outcomes, to include performance indicators, quality, $\mathrm{OCB}$, and employee productivity in the interaction between the variables could contribute to better interpretation. Longitudinal research could help to clarify how the relationship between the study variables changes through the various stages in the life-cycle of an organization, such as growth, decline, mergers, etc. Overall, this study provides scope for academics and practitioners to find the best HRM practices that would work for hotels so as to enhance OC.

\section{References}

Allen, D. G., Shore, L. M. \& Griffeth, R. W. (2003). The Role of Perceived Organizational Support and Supportive Human Resource Practices in the Turnover Process. Journal of Management, 29, pp. 99-118. 
Appelbaum, E., Bailey, T., Berg, P. \& Kalleberg, A. L. (2000). Manufacturing Advantage: Why High-Performance Work Systems Pay Off. Ithaca, NY: Cornell University Press.

Bakan, I., Büyükbeşe, T. \& Erşahan, B. (2011). An Investigation of Organizational Commitment and Education Level among Employees. International Journal of Emerging Sciences, 1(3), pp. 231-245.

Bartlett, K. R. (2001). The Relationship between Training and Organizational Commitment: A Study in the Health Care Field. Human Resource Development Quarterly, 12(4), pp. 335-352.

Baruch, Y. \& Holtom, B. (2008). Survey Response Rate Levels and Trends in Organizational Research. Human Relations, 61(8), pp. 1139-1160.

Blau, P. M. (1964). Exchange and Power in Social Life. New Brunswick, NJ: Transaction Publishers.

Boselie, P. (2010). Strategic Human Resource Management: A Balanced Approach. Birkshire: McGraw-Hill Higher Education.

Boselie, P., Dietz, G. \& Boon, C. (2005). Commonalities and Contradictions in HRM and Performance Research. Human Resource Management Journal, 15(3), pp. 67-94.

Boxall, P. \& Purcell, J. (2008). Strategy and Human Resource Management, Palgrave Macmillan.

Cantarello, S., Filippini, R. \& Nosella, A. (2012). Linking Human Resource Management Practices and Customer Satisfaction on Product Quality. International Journal of Human Resource Management, 23(18), pp. 39063924.

Chang, E. (2005). Employee's Overall Perception of HRM Effectiveness. Human Relations, 58(4), pp. 523-544.

Coyle-Shapiro, J. \& Kessler, I. (2000). Consequences of the Psychological Contract for the Employment Relationship: A Large Scale Survey. Journal of Management Studies, 37, pp. 903-930.

Dawson, M., Abbott, J. \& Shoemaker, S. (2011). The Hospitality Culture Scale: A Measure Organizational Culture and Personal Attributes. International Journal of Hospitality Management, 30(2), pp. 290-300.

Deery, M. A. \& Shaw, R. N., (1999). An Investigation of the Relationship between Employee Turnover and Organizational Culture. Journal of Hospitality and Tourism Research, 23(4), pp. 387-400.

Edgar, F. \& Geare, A. (2005). HRM Practice and Employee Attitudes: Different Measures Different Results. Personnel Review, 34(5), pp. 534-549. 
Egyptian Hotel Association (2016), Statistical Reports. Retrieved on August, 2016 from: http://www.egyptianhotels.org/Statistics.aspx

http://www.egyptianhotels.org/Hotels.aspx?id=HURGHADA

Eisenberger, R., Armeli, S., Rexwinkel, B., Lynch, P. D. \& Rhoades, L. (2001). Reciprocation of Perceived Organizational Support. Journal of Applied Psychology, 86, pp. 42-51.

Eisenberger, R., Huntington, R., Hutchison, S. \& Sowa, D. (1986). Perceived Organizational Support. Journal of Management Reviews, 71(3), pp.500-507. Eisenberger, R. \& Stinglhamber, F. (2011). Perceived Organizational Support: Fostering Enthusiastic and Productive Employees. Washington, DC: American Psychological Association.

Gardner, T. M., Wright, P. M. \& Moynihan, L. M. (2011). The Impact of Motivation, Empowerment, and Skill-Enhancing Practices on Aggregate Voluntary Turnover: The Mediating Effect of Collective Affective Commitment. Personnel Psychology, 64(2), pp. 315-350.

Gould-Williams, J. S. \& Gatenby, M. (2010). The Effects of Organizational Context and Team Working Activities on Performance Outcomes: A Study Conducted in England Local Government. Public Management Review, 12(6), pp. 759-787.

Guest, D. (2011). Human Resource Management and Performance: Still Searching for some Answers. Human Resource Management Journal, 21(1), pp. 3-13.

Hoque, K. (1999). Human Resource Management and Performance in the UK Hotel Industry. British Journal of Industrial Relations, 37(3), pp. 419443.

Iacobucci, D., Saldanha, N. \& Deng, X. (2007). A Meditation on Mediation: Evidence that Structural Equations Models Perform Better than Regressions. Journal of Consumer Psychology, 17(2), pp. 140-154.

Judge, T. A. \& Kammeyer-Mueller, J. D. (2012). Job Attitudes. Annual Review of Psychology, 63, pp. 341-367.

Katou, A. A. \& Budhwar, P. S. (2010). Causal Relationship between HRM Policies and Organizational Performance: Evidence from the Greek Manufacturing Sector. European Management Journal, 28(1), pp. 25-39.

Kehoe, R. R. \& Wright, P. M. (2013). The Impact of High-Performance Human Resource Practices on Employees' Attitudes and Behaviors. Journal of Management, 39(2), pp. 366-391.

Kusluvan, S. (2003). Characteristics of Employment and Human Resource Management in the Tourism and Hospitality Industry. In Kusluvan, S. (Ed.). 
Managing Employee Attitudes and Behaviors in the Tourism and Hospitality Industry. Nova Science Publishers, Inc. pp. 3-24.

Kwon, K., Bae, J. \& Lawler, J. (2010). High Commitment HR Practices and Top Performers Impacts on Organizational Commitment, Management International Review, 50(1), pp. 57-80.

Liu, W. (2004). Perceived Organizational Support: Linking Human Resource Management Practices with Important Work Outcomes. Unpublished PhD Thesis, University of Maryland, College Park, USA.

Maxwell, G. \& Steele, G. (2003). Organizational Commitment: A Study of Managers in Hotels. International Journal of Contemporary Hospitality Management, 15(7), pp. 362-369.

McGorry, S. Y. (2000). Measurement in a Cross-Cultural Environment: Survey Translation Issues. Qualitative Market Research, 3(2), pp. 74-81.

Messersmith, J. G., Patel, P. C., Lepak, D. P. \& Gould-Williams, J. S. (2011). Unlocking the Black Box: Exploring the Link between High-performance Work Systems and Performance. Journal of Applied Psychology, 96(6), pp. 1105-1118.

Meyer, J. P., Allen, M. J. \& Smith, C. A. (1993). Commitment to Organizations and Occupations: Extension and Test of a Three-component Conceptualization. Journal of Applied Psychology, 75(4), pp. 538-551.

Meyer, J. P. \& Allen, N. J. (1997). Commitment in the Workplace: Theory, Research and Application. Thousand Oaks, CA: Sage.

Meyer, J. P. \& Smith, C. A. (2000). HRM Practices and Organizational Commitment: Test of a Mediation Model. Canadian Journal of Administrative Sciences, 17(4), pp. 319-331.

Meyer, J. P., Stanley, D. J., Herscovitch, L. \& Topolnytsky, L. A. (2002). Affective, Continuance and Normative Commitment to the Organization: A Meta-Analysis of Antecedents, Correlates and Consequences. Journal of Vocational Behavior, 61(1), pp. 20-52.

Ogilvie, J. R. (1986). The Role of Human Resource Management Practices in Predicting Organizational Commitment. Group and Organizational Studies, 11(4), pp. 335-357.

Peterson, R. (1994). A Meta-Analysis of Cronbach's Coefficient Alpha. Journal of Consumer Research, 21(2), pp. 381-391.

Poulston, J. (2008). Hospitality Workplace Problems and Poor Training: A Close Relationship. International Journal of Contemporary Hospitality Management, 20(4), pp. 412-427.

Purcell, J. \& Hutchinson, S. (2007). Front-Line Managers as Agents in the HRM-Performance Causal Chain: Theory, Analysis and Evidence. Human Resource Management Journal, 17(1), pp. 3-20. 
Ram, P. \& Prabhakar, G. (2011). The Role of Employee Engagement in Work-Related Outcomes. Interdisciplinary Journal of Research in Business, 1(3), pp. 47-61.

Rhoades, L. \& Eisenberger, R. (2002). Perceived Organizational Support: A Review of the Literature. Journal of Applied Psychology, 87(4), pp. 698-714. Rhoades, L., Eisenberger, R. \& Armeli, S. (2001). Affective Commitment to the Organization: The Contribution of Perceived Organizational Support. Journal of Applied Psychology, 86(5), pp. 825-836.

Shore, L. M. \& Wayne, S. J. (1993). Commitment and Employee Behavior: Comparison of Affective and Continuance Commitment with Perceived Organizational Support. Journal of Applied Psychology, 78, pp. 774-780.

Singh, P., Finn, D. \& Goulet, L. (2004). Gender and Job Attitudes: A ReExamination and Extension. Women in Management Review, 19(7), pp. 345355.

Sobaih, A. E. (2015). Hospitality Employment Issues in Developing Countries: The Case of Egypt. Journal of Human Resources in Hospitality \& Tourism, 14(3), pp. 221-243.

Sobel, M. E. (1982). Asymptotic Intervals for Indirect Effects in Structural Equation Models. Social Methodology, 13(1), pp. 290-312.

Takeuchi, N. \& Takeuchi, T. (2013). Committed to the Organization or the Job? Effects of Perceived HRM Practices on Employees' Behavioral Outcomes in the Japanese Healthcare Industry. International Journal of Human Resource Management, 24(11), pp. 2089-2106.

Van Knippenberg, D. \& Sleebos, E. (2006). Organizational Identification versus Organizational Commitment: Self-Definition, Social Exchange, and Job Attitudes. Journal of Organizational Behavior, 27(5), pp. 571-584.

Wayne, S. J., Shore, L. M., Bommer, W. H. \& Tetrick, L. E. (2002). The Role of Fair Treatment and Rewards in Perceptions of Organizational Support and Leader-Member Exchange. Journal of Applied Psychology, 87, pp. $590-598$.

Wilton, N. (2006). Strategic Choice and Organisational Context in HRM in the UK Hotel Sector. The Service Industries Journal, 26(8), pp. 903-919.

Wood, S. \& de Menezes, L. (1998). High Commitment Management in the UK: Evidence from the WIRS and EMSPS. Human Relations, 51, pp. 485515.

Wright, P. M. \& Kehoe, R. R. (2008). Human Resource Practices and Organizational Commitment: A Deeper Examination. Asia Pacific Journal of Human Resources, 46(1), pp. 6-20. 
Yang, Y. (2012). High-Involvement Human Resource Practices, Affective Commitment, and Organizational Citizenship Behaviors. Service Industries Journal, 32(8), pp. 1209-1227.

Zafar, A., UlHaq, A., Usman, M. \& Hussain, N. (2014). Effects of Perceived Distributive Justice on Organizational Commitment: Mediating Role of Perceived Organizational Support. International Journal of Education and Research, 2(10), pp. 65-76. 